\title{
Comparison of antimicrobial activity of thymol and carvacrol to chlorhexidine in
}

\section{surgery}

\author{
Comparação da atividade antimicrobiana de timol e carvacról a clorexidina em cirurgia \\ Comparación de la actividad antimicrobiana del timol y el carvacrol con la clorhexidina en cirugía
}

Received: 05/19/2021 | Reviewed: 05/28/2021 | Accept: 05/29/2021 | Published: 06/13/2021

Danilo Chizzolini Masocatto ORCID: https://orcid.org/0000-0003-1784-371X Faculdade de Odontologia de Araçatuba, Brazil E-mail: danilomasocatto@hotmail.com

Mariza Akemi Matsumoto ORCID: https://orcid.org/0000-0001-5389-0105 Faculdade de Odontologia de Araçatuba, Brazil E-mail: mariza.am@gmail.com

Tulio Marcos Kalife Coelho

ORCID: https://orcid.org/0000-0003-3339-8011 Universidade Federal de Mato Grosso do Sul, Brazil E-mail: tulio.kalife@ufms.br

Ellen Cristina Gaetti Jardim

ORCID: https://orcid.org/0000-0003-2471-465X Universidade Federal de Mato Grosso do Sul, Brazil E-mail: ellen.jardim@ufms.br

José Carlos Garcia de Mendonça

ORCID: https://orcid.org/0000-0003-3217-872X Universidade Federal de Mato Grosso do Sul, Brazil E-mail: jose.mendonca@ufms.br

Júlio César Leite da Silva

ORCID: https://orcid.org/0000-0002-9835-7432 Universidade Federal de Mato Grosso do Sul, Brazil E-mail: julio.silva@ufms.br

Carlos Alexandre Carollo

ORCID: https://orcid.org/0000-0003-1231-9441 Universidade Federal de Mato Grosso do Sul, Brazil

E-mail: carlos.carollo@ufms.br

Aline Regina Carollo

ORCID: https://orcid.org/0000-0001-8717-8511 Universidade Federal de Mato Grosso do Sul, Brazil

E-mail: alinecarollo@gmail.com

Maria Carolina Silva Marques

ORCID: https://orcid.org/0000-0003-2854-1768 Universidade Federal de Mato Grosso do Sul, Brazil

E-mail: danilomasocatto@hotmail.com

Sonia Maria Fernandes

ORCID: https://orcid.org/0000-0002-7025-5987 Universidade Federal de Mato Grosso do Sul, Brazil

E-mail: sonia.fernandes@ufms.br

Jaqueline Suemi Hassumi

ORCID: https://orcid.org/0000-0002-5214-1214

Faculdade de Odontologia de Araçatuba, Brazil

E-mail: jaquelinehassumi@hotmail.com

Marina Gasparin Nogueira

ORCID: https://orcid.org/0000-0002-1628-703X Cirurgiã-dentista, Brazil

E-mail: marinagnog@hotmail.com

Francielly Thomas Figueiredo

ORCID: https://orcid.org/0000-0003-0196-1172 Universidade Federal de Mato Grosso do Sul, Brazil

E-mail: francielly_thomas@hotmail.com

André Hergesel de Oliva

ORCID: https://orcid.org/0000-0001-5818-9350

Faculdade de Odontologia de Araçatuba, Brazil

E-mail: holivaandre@gmail.com

Gustavo Silva Pelissaro

ORCID: https://orcid.org/0000-0003-3475-6001

Universidade Federal de Mato Grosso do Sul, Brazil E-mail: gustavopelissaro@hotmail.com 


\begin{abstract}
Currently, there is a constant search for new chemical compounds through plant extracts and phytochemical compounds that do not cause so many side effects in the oral cavity and that have good antimicrobial properties. Therefore, the present study evaluated the synergistic antimicrobial efficacy of mouthwashes containing thymol and carvacrol when compared with $0.12 \%$ chlorhexidine mouthwash after bilateral lower third molar extraction. Nineteen healthy (male and female) patients $(\mathrm{n}=19)$ aged between 18 and 30 years, of both sexes, treated at the Faculty of Dentistry of Mato Grosso do Sul (UFMS, MS, Brazil) participated in this study. All patients were submitted to two different therapeutic treatments, divided into two groups: group 1 (control) - patient used $0.12 \%$ chlorhexidine mouthwash solution; group 2 (experimental) - patient used $0.05 \%$ thymol and $0.025 \%$ carvacrol solutions. The suture was removed at seven postoperative days and aseptically transferred to a tube containing sterile potassium buffer saline solution. Samples were submitted to microbiological analysis at the Microbiology Laboratory at UFMS. The mean and standard deviation of colony forming units/ml of isolate microorganisms in the suture grown in BHI agar obtained from the control and experimental groups were 4.766 x $106 \pm 4.069$ and $4.847 \times 106 \pm 3.971$, respectively. In conclusion, the thymol and carvacrol based mouthwash showed antimicrobial effectivity in biofilm adherence of the silk thread after extraction of third molars.
\end{abstract}

Keywords: Oral surgery; Oral antiseptics; Phytochemical compounds.

\title{
Resumo
}

Atualmente, há uma busca constante por novos compostos químicos através de extratos vegetais e compostos fitoquímicos que não causem tantos efeitos colaterais na cavidade oral e que tenham boas propriedades antimicrobianas. Portanto, o presente estudo avaliou a eficácia antimicrobiana sinérgica de enxaguatórios bucais contendo timol e carvacrol quando comparados aos enxaguatórios bucais com clorexidina 0,12\% após a extração bilateral do terceiro molar inferior. Participaram deste estudo 19 pacientes saudáveis (homens e mulheres) $(n=19)$ com idades entre 18 e 30 anos, de ambos os sexos, atendidos na Faculdade de Odontologia de Mato Grosso do Sul (UFMS, MS, Brasil). Todos os pacientes foram submetidos a dois tratamentos terapêuticos distintos, divididos em dois grupos: grupo 1 (controle) - paciente em uso de solução para bochechos de clorexidina 0,12\%; grupo 2 (experimental) - paciente fez uso de solução de timol 0,05\% e carvacrol 0,025\%. A sutura foi removida sete dias após a cirurgia e transferida assepticamente para um tubo contendo solução salina tampão de potássio estéril. As amostras foram submetidas à análise microbiológica no Laboratório de Microbiologia da UFMS. A média e o desvio padrão das unidades formadoras de colônias/ml de microrganismos isolados na sutura cultivada em ágar BHI obtidos dos grupos controle e experimental foram 4,766 x $106 \pm 4,069$ e 4,847 x $106 \pm 3,971$, respectivamente. Em conclusão, o enxaguatório à base de timol e carvacrol apresentou eficácia antimicrobiana na aderência do biofilme do fio de seda após a extração dos terceiros molares.

Palavras-chave: Cirurgia oral; Antissépticos orais; Compostos fitoquímicos.

\section{Resumen}

Actualmente, existe una búsqueda constante de nuevos compuestos químicos a través de extractos de plantas y compuestos fitoquímicos que no provoquen tantos efectos secundarios en la cavidad bucal y que tengan buenas propiedades antimicrobianas. Por lo tanto, el presente estudio evaluó la eficacia antimicrobiana sinérgica de los enjuagues bucales que contienen timol y carvacrol en comparación con el enjuague bucal con clorhexidina al $0,12 \%$ después de la extracción bilateral del tercer molar inferior. En este estudio participaron 19 pacientes sanos (hombres y mujeres) $(n=19)$ de entre 18 y 30 años, de ambos sexos, atendidos en la Facultad de Odontología de Mato Grosso do Sul (UFMS, MS, Brasil). Todos los pacientes fueron sometidos a dos tratamientos terapéuticos diferentes, divididos en dos grupos: grupo 1 (control) - el paciente utilizó una solución de enjuague bucal con clorhexidina al 0,12\%; grupo 2 (experimental): el paciente utilizó soluciones de timol al 0,05\% y carvacrol al 0,025\%. La sutura se retiró siete días después de la operación y se transfirió asépticamente a un tubo que contenía solución salina tampón potásica estéril. Las muestras se sometieron a análisis microbiológico en el Laboratorio de Microbiología de la UFMS. La media y la desviación estándar de las unidades formadoras de colonias / $\mathrm{ml}$ de microorganismos aislados en la sutura cultivada en agar BHI obtenida de los grupos control y experimental fueron 4,766 x $106 \pm 4,069$ y 4,847 x $106 \pm 3,971$, respectivamente. En conclusión, el enjuague bucal a base de timol y carvacrol mostró efectividad antimicrobiana en la adherencia del biofilm del hilo de seda después de la extracción de terceros molares.

Palabras clave: Cirugía oral; Antisépticos orales; Compuestos fitoquímicos.

\section{Introduction}

Third molar extraction is one of the most common surgical procedures in dental clinics. It is extremely important to reposition the displaced soft tissue by using sutures. This procedure helps wound healing by maintaining the flap in place; by coapting the edges of the surgical wounds, stimulating healing by first intention. In addition, the suture avoids infections caused by penetration of food or foreign body in the alveolus and helps maintaining the integrity of the underlying bone to the 
soft tissue (Bucci et al., 2017).

Suture threads made of silk, cotton and nylon are most commonly used in intra-oral surgery (Santos \& Machado, 2001). Silk and cotton threads are widely used in oral surgery because they are easy to use, the knots do not untie easily (low memory), for their low tensile strength, low cost and their ends do not cause injury and ulceration in the buccal mucosa (Qin et al., 2010).

Adherence and colonization of oral cavity microorganisms on the surface of the suture is inevitable. The multiplication of these microorganisms may represent a focus of infection, interfering with the healing process. Thus, measures to ease the colonization and growth of microorganisms in the suture thread are of great importance to aid tissue regeneration and prevent possible complications.

One of the methods for oral environment adjustment and reduction of microflora is the use of oral rinses. Chlorhexidine has been widely used in the last 30 years and its antimicrobial activity largely evaluated. Chlorhexidine shows antibiofilm activity and antinflammatory effects in the gingival region; therefore, it is considered gold standard for clinical use. The $0.12 \%$ chlorhexidine mouthwash solution shows immediate microorganism reduction by $90 \%$ and its effect lasts from 30 seconds to 1 hour after the mouthwash, with a residual effect of up to 7h (Herrera et al., 2003; Catalán et al., 2008; Cousido et al., 2010). Despite the beneficial effects of chlorhexidine, there are some disadvantages, such as teeth color alterations, taste changes, metallic taste and high cost. Such disadvantages limit its use and stimulate the search for substitute solutions that are more affordable and with no side effects (Löe \& Schiött, 1970; Kocat et al., 2009).

Thus, the search for novel chemical compounds that do not cause as many side effects increases, such as the use of plant extracts and phytochemical compounds/chemical compounds, produced by plants, which have good antimicrobial properties associated with minimum side effects. Herbal medicine has been the subject of research and has been suggested as therapy for prevention and control of infectious oral diseases since its antimicrobial action mechanism is the impairment of bacterial cellular membrane integrity with loss of intracellular material and inhibition of respiration (Kwiecinski et al., 2009).

The global growth of herbal medicine - "the study of medicinal plants and their applications in the treatment of disease" (Ministry of Education) within preventive and curative programs has stimulated the evaluation of the activity of different plant extracts for the control of dental plaque.

Essential oils are natural products obtained by extraction from plants that are rich in "essences" belonging to the herbs called "aromatic" and medicinal plants. Once extracted, they feature oily, liquid, volatile and fragrance substances according to the plant they originate from. It is a very complex composition of substances that represent the noblest part of the plant, in the form of small drops of flower petals, fruit peel, resin, tree bark, roots of herbs and aromatic plants. They have been used in medicine and cosmetics, especially in dermatology and dentistry, among them eugenol, carvacrol and thymol can be mentioned (Freires et al., 2012).

Among the thousands of compounds that may be present in the composition of essential oils, thymol and carvacrol stand out due to their pronounced antimicrobial activities. They are the main constituents of the essential oils of various aromatic plants such as Thymus vulgaris, Origanium compactum, Acalypha phleoides and Lippia sidoides (Verbenaceae family). The characteristics of these compounds, such as low toxicity, solubility, availability and low cost are the main factors responsible for the emphasis on these aromatic monoterpenes (Peixoto-Neves et al., 2010).

Lippia sidoides is a medicinal herb that has been used in traditional medicine for a variety of antifungal and antimicrobial purposes. The two major constituents of the L. sidoides essential oils are thymol (50-59\%) and carvacrol (7$16 \%)$. Phenolic compounds such as carvacrol and thymol have an established large spectrum antimicrobial activity against yeasts and bacteria. Both compounds are also present in other essential oils (Botelho et al., 2007).

Then it is objectively to analyze the efficacy of the antimicrobial activity of the mouthwash containing thymol and 
carvacrol after bilateral lower third molar extraction and to compare the synergistic effect of the antimicrobial mouthwash containing thymol and carvacrol in relation to $0.12 \%$ chlorhexidine on adhesion of microorganisms in silk suture threads after lower third molar extraction.

\section{Methodology}

This split-mouth, double-blind, randomized study (Köche, 2011; Pelissaro et al., 2021; Hartmann Atuá et al., 2021 was submitted to analysis by the Research Ethics Committee of the Federal University of Mato Grosso do Sul (UFMS, MS, Brazil, 03/07/2017), as recommended by Resolution 466/2012 of the National Research Ethics Committee/National Health Council (CONEP/CNS). All patients signed an Informed Consent form (Appendix). The study is in agreement with the guidelines in the CONSORT - Consolidated Standards of Reporting Trials (2010), in order to guarantee the quality of the randomized clinical trial.

\section{Study Participants}

Nineteen healthy individuals with surgical risk ASA I (American Society of Anesthesiologists), i.e. healthy with no physiological, biochemical or psychiatric disorders aged between 18 and 30 years, of both sexes, attending the Faculty of Dentistry of Mato Grosso do Sul (FAODO - UFMS, Avenida Costa e Silva, University district, Campo Grande, MS, Brazil) took part in this study.

Participants who presented orthodontic indication for bilateral lower third molar extraction according to history, clinical and radiographic examination were included in the study. The position of the impacted third molar should be bilaterally similar, according to Pell and Gregory (1933) and Miller-Winter (1926) classifications. These classifications consider: Class I, enough space between ascending ramus of mandible and second molar to third molar accommodation (impacted); Class II, small space, i.e., space between ascending branch and distal portion of second molar is smaller than the mesiodistal diameter of third impacted molar; Class III: no space, i.e., third impacted molar is almost or entirely impacted in ascending ramus of mandible and; Position A, highest position of impacted tooth lies above occlusal plane or on the same line of the second molar; position B, highest position of impacted tooth is below occlusal plane and above the cervical line of the second molar; and position $\mathrm{C}$, highest position of impacted tooth is below the cervical line of the second molar. This classification was used to ensure lower variability in surgical trauma during surgery on both sides in each selected patient.

As for the exclusion criteria for surgical site, we considered third molars with any local event that might contraindicate the surgical procedure, such as pericoronitis, cysts or odontogenic tumors associated or not with third molars, trauma and any other clinical signs and/or symptoms at the surgical site. During anamnesis, exclusion criteria also included subjects; a) with systemic diseases and infections that could compromise surgery results or that contraindicated administration of study drugs; b) allergic to drugs and materials in the study; c) smokers; d) pregnant; e) nursing women making use of continuous medication (birth pills) or who used anti-inflammatory drugs or painkillers up to 15 days prior to participation in the study; f) making ongoing use of mouthwashes.

\section{Study design}

This study is classified as a clinical randomized double-blind, split-mouth, that is, a single patient undergoes two different therapeutic treatments: Group 1 (Control), participant used $0.12 \%$ chlorhexidine mouthwash; Group 2 (experimental), participant used a $0.05 \%$ thymol and $0.025 \%$ carvacrol mouthwash solution. There was a minimum interval of 14 days between treatments, so that the initial inflammatory process and healing of the first operated side did not interfere with the other. 
Participants received $8 \mathrm{mg}$ of dexamethasone orally 1 hour before surgery. For inflammation control and postoperative pain, the patients took Ibuprofen tablets ( 8 pills, $600 \mathrm{mg}, 12 / 12$ hours) for three days and paracetamol tablets (10 pills, $750 \mathrm{mg}$ ) as escape medication only in case of pain and/or fever, which were supplied to the study subjects. This regimen was chosen as participants were already under anti-inflammatory effect with possible analgesic effect.

Patients received two different treatments at different times, orally, outlined as follows: Protocol 1: $0.12 \%$ chlorhexidine mouthwash alone for 60 seconds just before surgery and continued 24 hours after surgery for 6 days; Protocol 2: mouthwash solution containing $0.025 \%$ carvacrol and $0.05 \%$ thymol for 60 seconds, just before surgery and continued 24 hours after surgery for 6 days.

The mouthwash was administered in a $250 \mathrm{ml}$ beaker. They were asked to wash their mouths with $15 \mathrm{ml}$ of the product to be tested for 60 seconds according to the method of METIN et al. (2006), twice daily (morning and evening) 30 minutes after brushing for 6 days. All flasks containing mouthwashes were equal, pre-identified by codes maintained by a second researcher, so that the operator and the participant did not know about the contents in the flasks. All mouthwashes had origin reports, performed by the Pharmacy Department of the Federal University of Mato Grosso do Sul (UFMS).

The side chosen for the first surgical procedure, as well as the protocol to be used were drawn. Thus, 19 patients were submitted to Protocol 1 in the first surgery and 19 patients were submitted to protocol 2 in the first surgery. The surgeon responsible for the procedure is a specialist in Oral and Maxillofacial Surgery and had no prior knowledge of which protocol was being used, as well as the participant did not know which protocol was being used (study classified as double blind).

\section{Surgical procedures}

The extra-oral antiseptic was carried out with a $2 \%$ chlorhexidine aqueous solution, and the intraoral one with a vigorous mouthwash according to the adopted protocol. Anesthesia of the lower alveolar and lingual nerves with anesthetic supplementation for the buccal nerve was performed using a carpule syringe with reflux (Duflex®, RJ, Brazil) with a 27G long needle (Unoject ${ }^{\circledR}$, DFL, Brazil). The anesthesia supplementation for the buccal nerve was performed in association, using a terminal subperiosteal infiltration anesthesia in the vestibular region of the fornix for better flap displacement, proper hemostasis and desensitization of the buccal nerve. For anesthesia, a 2\% mepivacaine hydrochloride with 1: 100.000 epinephrine (Mepiadre ${ }^{\circledR}$, DFL, Brazil) anesthetic solution was used and the maximum dose $(6.6 \mathrm{mg} / \mathrm{kg}$ ) was calculated according to the weight of each participant but taking into account the absolute dose of $400 \mathrm{mg}$ of anesthetic (Malamed, 2013).

Bilateral lower third molar extraction were performed by the same operator at the Faculty of Dentistry (FAODO UFMS, Campo Grande, MS, Brazil), in the morning (from 07:00 to 12:00), from August to December 2017, using the Mead incision. An X shaped suture was performed using 4-0 silk thread Shalon ${ }^{\circledR}$ and 3/8 cutting needle. Verbal and writing postoperative orientations were given.

The data analysis were performed by a professional who was blinded to the protocols evaluated. The mouthwashes were duly separated, coded as protocols 1 and 2, by a pharmacist who also took part in the research. Following, they were administered to patients and only identified at the end of the experiment, after statistical analysis.

\section{Postoperative guidelines}

At the end of surgery, patients were instructed to have a liquid/soft diet, rich in protein and cold for the first 24 hours postoperatively, besides other general care instructions such as no physical exercise, sun exposure or use of any mouthwash in the first 24 hours after the procedure. Patients who developed any post-operative complications, such as bleeding, or purulent or dry socket (dental alveolitis) were treated and consequently excluded from the study. 
Sample collection - Removal of sutures

The suture was removed on the seventh postoperative day. After removal, one of the suture lines was standardized and cut with $15 \mathrm{~mm}$ using a sterile endodontic millimeter ruler. The suture thread was then aseptically transferred to a tube containing $2 \mathrm{ml}$ of sterile saline solution of 0.1 potassium phosphate buffer $(0.9 \% \mathrm{NaCl}), \mathrm{pH} 7.2$. Samples were transferred to the Microbiology Laboratory (FACFAN - UFMS, Campo Grande, MS, Brazil) maintaining the necessary conditions for microbiological analysis.

\section{Microbiological evaluation}

The test tube with suture samples were vortexed for 2 minutes to obtain a first homogeneous mixture. Decimal dilutions $(10-1,10-2,10-3)$ were then prepared from this suspension in sterile saline solution. Aliquots of $0.1 \mathrm{ml}$ of stock solutions and dilutions were plated in duplicate into Petri dishes containing Agar Brain Heart Infusion (BHI) as a culture medium and prepared for total counts of facultative aerobic and anaerobic microorganisms. The agar plates were incubated at $37^{\circ} \mathrm{C}$ in microaerophilic conditions for $24-48$ hours and the plates containing colony forming units were counted per milliliter (CFU/ml).14

The data were analyzed statistically by Student`s t-test at 5\% significance level.

\section{Results}

Table 1 show the mean and standard deviation of colony forming units [CFU/ml $\left.\left(10^{6}\right)\right]$ of isolated suture microorganisms grown on BHI agar obtained from the control ( $0.12 \%$ chlorhexidine) and thymol and carvacrol extract groups.

The mean number of colony forming units $/ \mathrm{ml}\left(\mathrm{x}_{10} 0^{6}\right)$ of facultative aerobic and anaerobic microorganisms grown in Brain Heart Infusion (BHI) is shown in figure.

There were no statistically significant differences in microbial reduction between the control and the thymol and carvacrol extract groups.

Table 1. Mean and standard deviation of colony forming units [CFU/ml (106)] of isolated suture microorganisms grown on BHI agar obtained from the control $(0.12 \%$ chlorhexidine) and thymol and carvacrol extract groups. a - means identified with same letter are statistically similar (Student's t-test).

\begin{tabular}{|c|c|c|c|}
\hline Group & CFU/ml $(\log 10)$ & Confidence interval & $p$ \\
\hline chlorhexidine 0,12\% & $4,766 \pm 4,069^{\text {a }}$ & $2,804-6,727$ & $\geq 0,05$ \\
\hline $\begin{array}{c}\text { thymol and carvacrol } \\
\text { extract }\end{array}$ & $4,847 \pm 3,971^{\text {a }}$ & $2,933-6,761$ & $\geq 0,05$ \\
\hline
\end{tabular}

Source: Authors (2021).

\section{Discussion}

Suture threads used in oral surgery, especially the silk ones, are easily colonized for being multifilament silk. However, they are the most frequently used ones because they are inexpensive, easy to handle, exhibit low memory and have no sharp edges that irritate the buccal mucosa (Cuffari \& Siqueira, 2007). The sutures performed with this thread are incorporated into the oral tissue and bathed in saliva, which has an average concentration of microorganisms of approximately $7.5 \times 108$ microorganisms $/ \mathrm{ml}$. When used in oral and gingival mucosa, they may therefore produce prolonged inflammatory 
responses in the tissue, as they are a continuous reservoir of microbial contamination along the suture (Faria et al., 2011). This study showed a significant decrease in microorganism concentrations in relation previous studies.

The antiseptic solutions are used in various situations, both prophylactic and therapeutic. Chlorhexidine is considered the gold standard in dental research or dental practice, due to the excellent results for microbiota control. However, it has many side effects, such as staining of tooth and restorations, altered taste and metallic taste (Catalán et al., 2008; Cousido et al., 2010). Thus, herbal compounds, which produce less side effects compared to chlorhexidine are searched for as an alternative treatment, since they have already proven their antimicrobial, antiviral, antifungal and antiinflammatory action (Botelho et al., 2007; Rodrigues et al., 2009; Lauritano et al., 2016). The methodology adopted in the present study was based on these precepts, since the patients used mouthwash before and after surgery in order to reduce the oral microbiota to the maximum, thus avoiding infectious postoperative complications.

This study was the first to evaluate the in vivo effect of the synergistic action of thymol and carvacrol on the degree of contamination in silk sutures after surgery of lower third molar extraction. Previous studies also analyzed the in vivo effect, but aimed at evaluating the effects of the Lippia sidoides-based mouthwash on gingival inflammation and dental plaque in patients with gingivitis(Botelho et al., 2007; Rodrigues et al., 2009; Lauritano et al., 2016) and on the production of S. mutans in children with cavities (Lobo et al., 2014).

The mouthwash containing thymol and carvacrol showed similar results $(\mathrm{p} \geq 0.05)$ when compared to chlorhexidine in the present study. Chlorhexidine is known as the first choice mouthwash after oral surgery, due to its safety and proven efficacy. However, numerous adverse effects are described in literature. Thus, there is a great demand for antibacterial mouthwashes that have properties similar to chlorhexidine, however without the side effects (Nogueira et al., 2013). This much desired antibacterial property is due to the fact that any infectious process necessarily comprises a first step consisting in bacterial adhesion to surfaces (Gebara et al., 1996; Kohlert et al., 2000).

Studies performed with essential Lippia sidoides oil mouthwashes containing thymol and carvacrol showed antibacterial activity against S. mutans, bacteria considered cariogenic, with positive results (Rodrigues et al., 2009; Lobo et al., 2014; Nogueira et al., 2013; Nunes et al., 2006). Nevertheless, thymol and carvacrol mouthwashes have not yet been tested in suture threads in the oral environment. Hence, it is of paramount importance that this study in addition to seeking viable alternative replacement for chlorhexidine, also tries to stimulate further research on natural substances with effects similar to what is regarded as gold standard. The thymol and carvacrol solution are eight times lower priced and has fewer adverse effects than the chlorhexidine one.

The biofilm in sutures is an issue to which the dental community searches solution, as this accumulation of bacteria near the wound can lead to chronic microbial infection, tissue necrosis and delayed healing process of surgical wounds. That said, the importance of the use of antiseptic mouthwashes to decrease bacterial adherence to the suture is a unique and recommended approach. This simple procedure reduces the risk of transient bacteremia, indicated especially in patients predisposed to bacterial endocarditis, those with immune dysfunction or even those who are under postoperative maxillomandibular blockage (Qin et al., 2010).

The test results showed that the amount of formed colony units was similar regardless of the use of $0.12 \%$ chlorhexidine mouthwash or $0.05 \%$ thymol and $0.025 \%$ carvacrol mouthwash. This leads us to believe that the experimental mouthwash used in this study showed great and significant results, confirming the possibility of using it as a reliable alternative.

In this research study, the two mouthwashes showed a similar effect. Demonstrating that compared with other studies where the substances are used separately, the experimental mouthwash has antibacterial and non-adhering effects potentiated when used in combination (García-García et al., 2011). These results support some in vitro (Albuquerque et al., 2013) and in 
vivo studies (Botelho et al., 2007; Rodrigues et al., 2009; Lobo et al. 2014; Nunes et al., 2006) and contrasts the study of Lauritano et al. (2016), who tested the synergistic activities of the two components in oral bacteria.

The present study is relevant as the results obtained can guide and answer questions of clinical interest and influence future decisions of professionals regarding a possible replacement for chlorhexidine for oral antisepsis. In addition, our data stimulate further studies using new plant extracts and phytochemical compounds, in order to develop inexpensive oral health treatments for low socioeconomic income communities.

\section{Conclusion}

The thymol and carvacrol based mouthwash is effective in antimicrobial activity on biofilm adhesion in 4-0 silk threads after extraction of third molars compared with the $0.12 \%$ chlorhexidine-based mouthwash. More researches are needed in order to expand knowledge about the same.

\section{Acknowledgments}

We thank Coordenação de Aperfeiçoamento de Pessoal de Nível Superior (CAPES) for supporting this work.

\section{References}

Albuquerque, A. C. L., Pereira, M. S. V., Silva, D. F., Pereira, L. F., Viana, F. A. C., Higino, J. S. et al. (2013). The anti-adherence effect of Lippia sidoides Cham. Extract against microorganisms of dental biofilm. Rev Bras Pl Med, 15(1):41-6.

Botelho, M. A., Bezerra Filho, J. G., Correa, L. J., Fonseca, S. J. C., Montenegro, D., et al. (2007). Effect of a novel essential oil mouthrinse without alcohol on gingivitis: a doubleblinded randomized controlled Trial. J Appl Oral Sci, 15(3):175-80.

Bucci, M., Borgonovo, A., Bianchi, A., Zanellato, A., Re, D. (2017). Microbiological analysis of bacterial plaque on three different threads in oral surgery. Minerva Stomatol, 66(1):28-34.

Catalán, A., Pacheco, J. G., Martínez, A., Mondaca, M. A. (2008). In vitro and in vivo activity of Melaleuca alternifolia mixed with tissue conditioner on Candida albicans. Oral Surg Oral Med Oral Pathol Oral Radiol Endod, 105(3):327-32.

Cousido, M. C., Carmona, I. T., García-Caballero, L., Limeres, J., Álvarez, M., Diz, P. (2010). In vivo substantivity of 0.12\% and 0.2\% chlorhexidine mouthrinses on salivary bacteria. Clin Oral Invest, 14(4):397-402.

Cuffari, L., Siqueira, J. T. T. (2007). Suturas em cirurgia oral e implantodontia. Rev Bras Implant, 3(4):12-7.

Faria, R. L., Cardoso, L. M. L., Akisue, G.; Pereira, C. A., Junqueira, J. C., Jorge, Santos Júnior, A. O. C. (2011). Antimicrobial activity of Calendula officinalis, Camellia sinensis and chlorhexidine against the adherence of microorganisms to sutures after extraction of unerupted third molars. $J$ Appl Oral Scl, 19(5):476-82.

Freires, I. A., Silva, I. C., Alves, L. A., Bezerra, L. M., Castro, R. D. (2012). Clinical applicability of natural product(s)-containing mouthwashes as adjunctive treatment of biofilm-induced gingivitis: A systematic review. Braz J Med Plants, 14(6), 700-11.

García-García, R., López-Malo, A., Palou, E. (2011). Bactericidal action of binary and ternary mixtures of carvacrol, thymol, and eugenol against Listeria innocua. J Food Sci, 76(6), 95-100.

Gebara, E. C. E., Zardetto, C. G. C., Mayer, M. P. A. (1996). Estudo in vitro da ação antimicrobiana de substâncias naturais sobre S. mutans e S. sobrinus. Revista de Odontologia da USP, 10(1):251-6.

Hartmann Atuá, R., Pereira, K. F. S., Gaetti Jardim, E. C., Zafalon, E. J., de Freitas Boscaine, E., \& Silva, J. C. L. da. (2021). Emprego do Laser de baixa intensidade no pós-operatório de exodontia de terceiros molares. ArcHI, 10(3), 489-496.

Herrera, D., Santacruz, I., Santos, S., Masdevall, M., Sanz, M. (2003). Differences in antimicrobial activity of four commercial 0.12\% chlorhexidine mouthrinse formulations: an in vitro contact test and salivary bacterial counts study. J Clin Periodontol, 30(4):307-14.

Kocat, M. M., Ozcanb, S., Kocakb, S., Topuzc, O., Ertend, H. (2009). Comparison of the Efficacy of Three Different Mouthrinse Solutions in Decreasing the Level of Streptococcus Mutans in Saliva. Eur J Dent, 3(1):57-61.

Kohlert, C., Van Rensen, I., März, R., Schindler, G., Graefe, E.U., Veit, M. (2000). Bioavailability and pharmacokinetics of natural volatile terpenes in animals and humans. Planta Med, 66(12):495-505.

Kwiecinski, J., Eick, S., Wójcikm, K. (2009). Effects of tea tree (Melaleuca alternifolia) oil on Staphylococcus aureus in biofilms and stationary growth phase. Int J Antimicrob Agents, 33(4):343-7. 
Research, Society and Development, v. 10, n. 7, e4310716310. 2021

(CC BY 4.0) | ISSN 2525-3409 | DOI: http://dx.doi.org/10.33448/rsd-v10i7.16310

Lauritano, D., Pazzi, D., Iapichino, A., Gaudio, R. M., Di Muzio, M., Lo Russo, et al. (2016). Evaluation of the efficacy of a new oral gel containing carvacrol and thymol for home oral care in the management of chronic periodontitis using per analysis: a microbiological pilot study. J Biologic Regulators \& homeostatic agents, 30(2):129-34.

Lobo, P. L. D., Fonteles, C. S. R., Marques, L. A. R. V, Jamacaru, F. V. F., Fonseca, S. G. C., Moraes, M. E. A. (2014). The efficacy of three formulations of Lippia sidoides Cham. essential oil in the reduction of salivary Streptococcus mutans in children with caries: A randomized, double-blind, controlled study. Phytomedicine, 45(4);1043-7.

Löe, H., Schiött, C. R. (1970). The effect of mouth rinses and topical application of chlorhexidine on the development of dental plaque and gingivitis in man. $J$ Periodontal Res, 5(2):79-83.

Malamed, S. F. (2013). Handbook of Local Anesthesia. 6th Edition. 432p.

Nogueira, M. N. M., Correia, M. F., Fontana, A., Bedran, T. B. L., Spolidorio, D. M. P. (2013). Avaliação Comparativa "In Vivo" da Eficácia do Óleo de Melaleuca, Clorexidina e Listerine sobre Streptococcus mutans e Microrganismos Totais na Saliva. Pesq Bras Odontoped Clin Integr, João Pessoa, 13(4):3439.

Nunes, R. S., Lira, A. A. M., Lacerda, C. M., Silva, D. O. B., Silva, J. A., Santana, D. P. (2006). Obtention and evaluation of odontologic products made with the crude extract of Lippia sidoides Cham (Verbenaceae) over the dental biofilm. Rev Odontol UNESP, 35(4):275-83.

Peixoto-Neves, D., Silva-Alves, K. S., Gomes, M. D., Lima, F.C., Lahlou, S., Magalhães, P. J, et al. (2010). Vasorelaxant effects of the monoterpenic phenol isomers, carvacrol and thymol, on rat isolated aorta. Fundam Clin Pharmacol, 24(6):341-50.

Pelissaro, G. S., Silva, T. F. R. G. da., Herculano, A. B. de S., Santos, M. E. S. dos., Oliveira, B. C., Silva, J. C. L. da., Marion, J. J. de C., Faverani, L. P., Sandim, G. B., Souza, A. S., Jardim, E. C. G. (2021). Kinesio tape for edema control after bichectomy: A randomized trial study. RSD, $10(5)$ : e33610514983.

Qin, Y., Wang, H., Karuppanapandian, T., Kim, W. (2010). Chitosan verde cura. Chin J Traumatol, 13(2):91-5.

Rodrigues, I. S. C., Tavares, V. N., Pereira, S. L. S., Costa, F. N. (2009). Antiplaque and antigingivitis effect of lippia sidoides. a double-blind clinical study in humans. J Appl Oral Sci, 17(5):404-7.

Santos, M. A. M., Machado, J. L. (2001). Colaboração ao estudo de fios utilizados em suturas alveolares, avaliação histológica e clinica do fio dental. Rev Fac Odontol UFBA, 23(2):28-32. 